\title{
近年に於ける有機アルカリ金屬化合物の發展
}

\author{
津田恭介 \\ (東京帝國大學醫學部薬學科藥化學教宝) \\ 序 $\overrightarrow{\overline{\bar{\sigma}}}$
}

此處に有機アルカリ金屬化合物と䊈する物は Me-R (Me. Alkalimetall, R：Alkyl, Aryl, Amin）型の有機化合物を指すのて西つて，本稿は K. Zlegler 教授の最近に於ける之等化合物 の不飽和原子團（ $>\mathrm{C}=\mathrm{C}<,>\mathrm{C}=\mathrm{N}$ -,$-\mathrm{C} \equiv \mathrm{N} ）$ 飞對する興味ある化學反應を探錄し以て一 文に草したものである. 本諭に入るに先立ち有機アルカリ金屬化合物が化學界に出現し來つた 歴史を一憼し，K. Ziegler 以前に於ける此の方面の研究を理解するのに便ならしめたい.

有機アルカリ金屬化合物を系統的に研究した最初の人は遊離有機枳 (free Radikale) の開拓 者として著名である所のW. Schlenk 敉授である 同氏か此方面に于を杂めた第一步は Metallketyl の研究てあつた 1891 年に Beckmann は Benzophenon, Phenyl-a-naphtylketon のエー テル溶夜に空氣を遮斷した牀態てナトリウムを作䏳せしると着色したナトリウム化合物を成 生する事を發見したのてあるが此の新化合物の構造に關しては全く知るを得なかつた 偶な 1900 年 Gomberg か Hexaphenylathan の溶液內に於ける解離現象を發見，其の後 W Schlenk の系統的な Hexaarylathan 系化合物の解離現象の研觉に由り此處に遊離存機根郎ち三價の炭 素化合體の一群が出現する事となつた

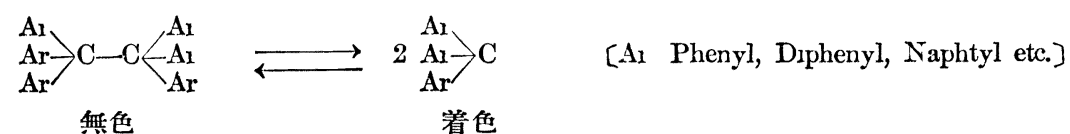

W. Schlenk は上記 Beckmann の發見になるケトンのナトリウム化合體が三價炭素化合物な るべき事を豫想し各種の化學的性狀を探究した結果次ぎの樣な構造を有する事を明らかにして 此の豫想の誤りで無い事を確めた (1911 年).

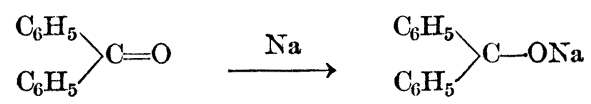

W. Schlenk は此のケトンナトリウム監を Metallketyl と䊈し，更に何一原子のナトリウム が附加する事を明かにした 


$$
\begin{aligned}
& \mathrm{C}_{6} \mathrm{H}_{5} \\
& \mathrm{C}_{6} \mathrm{H}_{5}
\end{aligned}>\mathrm{C}-\mathrm{ONa} \stackrel{\mathrm{Na}}{\longrightarrow} \quad \begin{aligned}
& \mathrm{C}_{6} \mathrm{H}_{5} \\
& \mathrm{C}_{6} \mathrm{H}_{5}
\end{aligned} \underset{\mathrm{Na} \mathrm{Na}}{\mathrm{C}-\mathrm{O}}
$$

同氏は $>\mathrm{C}=\mathrm{O}$ 基以外の二重結合にナトリウム附加反應が行はれるか否かを檢し Phenyl 基に隣接する $>\mathrm{C}=\mathrm{C}<,>\mathrm{C}=\mathrm{N}$ 一， $-\mathrm{N}=\mathrm{N}$ 一, 等が何れも同樣の反應を行ふのを知つた. 例 ヘば
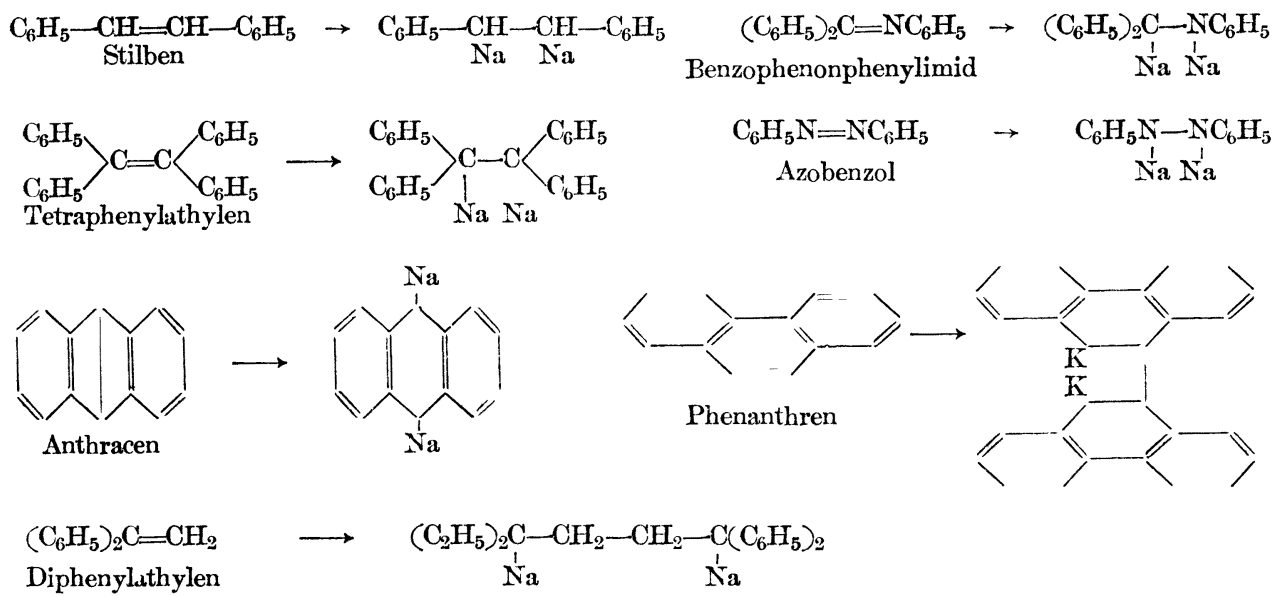

问上注遊離有機根である所の Triphenylmethyl が容易に $\left(\mathrm{C}_{6} \mathrm{H}_{5}\right)_{3} \mathrm{CNa}$ をる化合物を成生する 事を確め更に進んで次の如き一群の比較的簡單な有機アルカリ金屬化合體を合成するのに成功 Lた (1917 年). $\mathrm{NaCH}_{3}, \mathrm{LiCH}_{3}, \mathrm{NaC}_{2} \mathrm{H}_{5}, \mathrm{LiC}_{2} \mathrm{H}_{5}, \mathrm{NaC}_{3} \mathrm{H}_{5}, \mathrm{NaC}_{6} \mathrm{H}_{5}, \mathrm{LiC}_{6} \mathrm{H}_{5}, \mathrm{NaCH}_{2} \mathrm{C}_{6} \mathrm{H}_{5}$ 以上の化合物中 Triphenylmethylnatrium 及び Benzylnatrium はェーテル溶液中でイオン化を 行ひ電流を通すので有名である（B 47, 1678；49,601).

上記 W. Schlenk の研究は有機アルカリ金屬化合物の一群を磼立した點に於て重要であるが 又他の方面に於て 1900 年頃 Acetylen, Inden, Fluoren, Diphenylmethan 等の活性メチレン基 がアルカリと置換する事が明らかにされてるる.

$\mathrm{NaC} \equiv \mathrm{CNa}$

Acetylen-Na

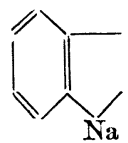

Inden-Na

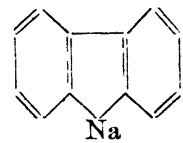

Fluoren-Na
$\left(\mathrm{C}_{6} \mathrm{H}_{5}\right)_{2} \mathrm{CHNa}$

Diphenylmethan-Na

有機アルカリ金屬化合物の分類

有機アルカリ金䐂化合物を次の三群に大別するてとが出來る.

I 無色. 有機溶媒に不溶である所の $\mathrm{Na}, \mathrm{K}$-Alkyl 及 -Aryl $\left(\mathrm{KC}_{2} \mathrm{H}_{5}, \mathrm{NaC}_{6} \mathrm{H}_{5}\right)$ であ 
つて, Znnkalkyl に溶かすと其溶夜は電流を通す（Z a Ch 141, 161) 固態で異極性 (heteropolar）構造を有すると考へられる物てある 通常の有機溶媒に不溶なるが故に取扱ひ困難で後 迌の種々な反應試藥としては使用されて居ない。

II. 着色 有機溶媒 (Aether, Benzol) に溶解し，此の溶夜は電流を通す，此の類に屬する 化合物はアルカリ金屬に結合した炭素か Aryl 基又は二重結合原子團に直結してるる，例へば $\mathrm{NaCH}_{2} \mathrm{C}_{6} \mathrm{H}_{5}, \mathrm{KC}\left(\mathrm{CH}_{3}\right)_{2} \mathrm{C}_{6} \mathrm{H}_{5}, \mathrm{C}_{6} \mathrm{H}_{5} \mathrm{CHLiCHL} \mathrm{C}_{6} \mathrm{H}_{5}, \mathrm{RCH}_{2} \mathrm{CH}=\mathrm{CHCH}_{2} \mathrm{~K}$ W. Schlenk のア ルカリ附扣反應成續體, 遊離有機根のアルカリ鹽, 後术の Ziegler 反應成績體等何れも此の類 に屬し最も取扱ひの簡單なものてある

III 椇色. 有機溶媒（Aether, Benzol) に溶解し此の溶夜は電流を通さない，之に屬するも のは Ll-Alkyl 及び Aryl のみてあつて，Zınkalkyl と同樣同極性 (homoopolar) 構造を有す ると考へられる

一 般 性 狀

I 何れも無色乃至着色した粉末として得られるが上記分類の II, III 屬に屬する物は有機 溶媒に溶解するが故にエーテル，カソリン等から再結晶を行ふ事が出來る．何れも熱に由り分 解するが故正確な融點は有しない

II. 空氣及び水分に極めて銳敏てあつて簡單なアルキル化合物は空氣に觸れると發火し，又 水分に由り荷性アルカリを遊離して 炭化水素を復生するが故製法に於ても非常に注意を要し窒 素氣流中無水溶媒中に於て作る 故に後迌の Ziegler の諸反應に使用する試藥は 固態として得 る事の困難な妥め溶媒中に製した有機アルカリ金屬化合體の溶夜を其儘使用してるる

III. 炭酸瓦斯と容易に反應してカルホキシル基を新生する.

$$
\mathrm{R}-\mathrm{K} \stackrel{\mathrm{CO},}{\longrightarrow} \quad \mathrm{R}-\mathrm{CO}_{2} \mathrm{~K}
$$

IV. ハロ ゙ンアルキルと異極性化合物てあるII 屬の物は瞬間的に反應してアルキル基とアル カリは置換するがIII屬の物は同極性化合物に屬するが故此の反應を極めて行ひ難い特徵がある.

$$
\mathrm{R}-\mathrm{K}+\mathrm{C}-\mathrm{R}^{\prime} \quad \longrightarrow \quad \mathrm{R}-\mathrm{R}^{\prime}+\mathrm{K}-\mathrm{Cl}
$$

製法

有機アルカリ金屬化合物の一般的製法は有機水銀化合物とアルカリ金屬に由る置換反應てあ つて W. Schlenk が始めて此の方法を發見し爾來現今に至るも佾踏襲して居る.

$$
\mathrm{HgR}_{2}+2 \mathrm{Na}=2 \mathrm{NaR}+\mathrm{Hg}
$$

此の合成法立びに W. Schlenk のアルカリ附加反應は Houben-Weyl, Bd IV. 947 に詳細 て記迌されてねるが故に參照されたいＫ Ziegler は Phenylisopropylkalium 及び Li-Alkyl, $-64-$ 
Aryl の簡單な合成法を發見し，之を試樂として後述の種々な反應を行つた. 其の合成法は次 の如くである.

I. Phenylisopropylkalium の製法 (Ann. 473, 1). Phenylisopropylmethylaether のエーテル 溶液にナトリウムカリウム合金を加へ二日間放置，かくして得た Phenylisopropylkalium のエ ーテル溶液を使用する.

$$
\mathrm{C}_{6} \mathrm{H}_{5}\left(\mathrm{CH}_{3}\right)_{2} \mathrm{COCH}_{3}+2 \mathrm{~K} \quad \longrightarrow \quad \mathrm{C}_{6} \mathrm{H}_{5}\left(\mathrm{CH}_{3}\right)_{2} \mathrm{CK}+\mathrm{KOCH}_{3}
$$

此溶液中に於ける Phenylisopropylkalium の力價は次の如くにして定める 郎ち此の溶液に Butylbromid を加へ過剩の Butylbromid は減壓で溜去し，反應成績體であるブロムカリを水 溶夜となし，溶液中のブロムを定量する。

$$
\mathrm{C}_{6} \mathrm{H}_{5}\left(\mathrm{CH}_{3}\right)_{2} \mathrm{CK}+\mathrm{C}_{4} \mathrm{H}_{9} \mathrm{Br}=\mathrm{C}_{6} \mathrm{H}_{5}\left(\mathrm{CH}_{3}\right)_{2} \mathrm{CC}_{4} \mathrm{H}_{9}+\mathrm{KBr}
$$

II Li-Alkyl, Aryl の製法 (Amn 479, 135). Wurz-Fittig 反應として知られてるる炭化水 素合成法は次ぎの二段の反應に分ける事が出來る.

$$
\begin{aligned}
& \text { I. } \mathrm{RX}+2 \mathrm{Me}=\mathrm{RMe}+\mathrm{MeX} \\
& \text { II. } \mathrm{RMe}+\mathrm{R}^{\prime} \mathrm{X}=\mathrm{R}-\mathrm{R}^{\prime}+\mathrm{MeX}
\end{aligned}
$$

Li-Alkyl, Aryl は上述の如くハロゲンアルキルとの反應速度が小である䉆め II の反應が進 行しにくい. 例へはェーテル中に於ける $\mathrm{LiC}_{4} \mathrm{H}_{9}$ と八ロゲンブチルとの反應速度は

$$
\begin{aligned}
& \mathrm{Li} \mathrm{C}_{4} \mathrm{H}_{9}+\mathrm{J} \mathrm{C}_{4} \mathrm{H}_{9} \text { 瞬間的に反應する } \\
& \text { ” }+\mathrm{BrC}_{4} \mathrm{H}_{9} \quad 5 \text { 時間に”, } \\
& ״ \quad+\mathrm{Cl} \mathrm{C}_{4} \mathrm{H}_{9} \quad 40 \text { 時間で } 50 \% \text { 進も。 }
\end{aligned}
$$

ベンツォール中では

$$
\begin{aligned}
& \mathrm{Li} \mathrm{C}_{4} \mathrm{H}_{9}+\mathrm{J} \mathrm{C}_{4} \mathrm{H}_{9} \quad 3 \text { 時間て } 50 \% \text { 進泉. } \\
& \text { ” }+\mathrm{BrC}_{4} \mathrm{H}_{9} \text { 3-4日て " , } \\
& \text { ” }+\mathrm{ClC}_{4} \mathrm{H}_{9} \text { 日で ”, }
\end{aligned}
$$

Li-Aryl はェーテル, ベンツォール中でハロダンアルキルと反應しない.

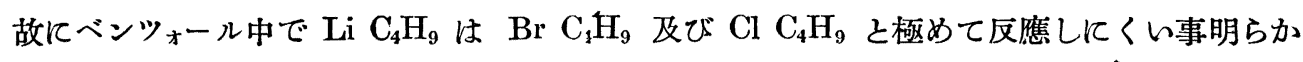
で斯くしてベンツォール中では Wurz-Fittig 反應はＩ反應のみ行はれて II 反應は行はれに くレ事が制る.

事實アルキルブロミドはリチウムと作用せしめるとエーテル中ではアルキルリチウムの收量 15\%に過ぎねがベンツォール中では 50-60\%に登る. クロリドはェーテル中 50-60\% ベンツォ ール中 80-100\%の收量を以てアルキルリチウムを成生する. 例へば等量のブチルブロミドと リチウムはベンツォール中 24 時間 $35^{\circ}$ に放置するとブチルリチウムを $57 \%$ の收量を以て成 
生する. $\mathrm{Lu}_{6} \mathrm{H}_{5}$ はベンツォールに不溶である䍃めエーテルを溶媒として作る。此等の Li-Alkyl, Aryl は其の溶夜の儘試藥として用ふるのであるが力價は次の如くにして定める。

Li-Alkyl, Aryl は $\mathrm{C}_{4} \mathrm{H}_{9} \mathrm{Br}$ との反應が䌊和である妥め此の兩者の混液中に更に $\mathrm{Hg}\left(\mathrm{CH}_{2}\right.$ $\left.\mathrm{C}_{6} \mathrm{H}_{5}\right)_{2}$ を加へる. 斯くして生成した $\mathrm{L}_{1} \mathrm{CH}_{2} \mathrm{C}_{6} \mathrm{H}_{5}$ は瞬間的に $\mathrm{C}_{4} \mathrm{H}_{9} \mathrm{Br}$ と反應するか故過剩 の $\mathrm{C}_{3} \mathrm{H}_{9} \mathrm{Br}$ を留去して然る後に $\mathrm{LiBr}$ を水溶夜にして $\mathrm{Br}$ を定量する.

之等の Phenylisopropylkalium, Li-Alkyl, Aryl は空 氣，水に對して銃敏である弯制造に際して特殊の反應 容器を用ひ，エーテル， ベンツォールは Benzophenonnatrium で脫水，水素氣流中て蒸留して使用する，即ち 容器 A の上頸から溶媒, 試藥を加へ側頸から䇪素を通 じて窒素氣流中に兩頸とも熔接して反應せしめるのてあ る. 反應完結後試藥として使用する場合は反應夜を計量 器の附屬した B なる容器に窒素氣流中に憈過して移し 力偪を測定した後此の一定量を使用する. 後述の Ziegler の各種の反應は何れも容器 $\mathrm{A}$ を使用し之に容器 $\mathrm{B}$ か ら一定量の有機アルカリ金屬化合物及び他の試藥を入れ
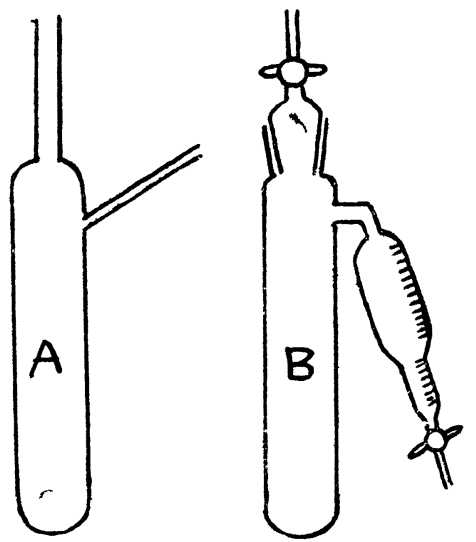
て窒素氣流中に熔接して反應せしめる.

不飽和炭化水索に對する反應

I 附加反應

WV Schlenk は Styrol (B 47, 476), 1-Phenylbutadien (Houben-Weyl, Bd IV, 971) かエ ーテル中ナトリウムに由り高級重合體（Hochpolymer）を成生する事を報告してなるか其間の 反應機作に關しては全く明かににされてねない K Ziegler が有機アルカリ化合體の種ふな反 應を開始した動機は Stılben に Phenylisopropylkalıum を作用せしめ置換反應を行つて會て Schlenk が得た所の Stilbendıkalıum を作らうとしたのであるが豫期に反し附加成績體を得て 之に $\mathrm{CO}_{2}$ を通する事に由り $\mathrm{Fp} 246^{\circ}$ 及び $\mathrm{Fp} 216^{\circ}$ のチストランス附加體カルボン酸を得た (B. 61, 253).

$$
\begin{aligned}
& \mathrm{C}_{6} \mathrm{H}_{5} \mathrm{CH}=\mathrm{CHC}_{6} \mathrm{H}_{5} \quad \stackrel{\mathrm{C}_{6} \mathrm{H}_{5}\left(\mathrm{CH}_{3}\right)_{2} \mathrm{C} \cdot \mathrm{K}}{\longrightarrow} \underset{\mathrm{C}_{6} \mathrm{H}_{5}\left(\mathrm{CH}_{3}\right)_{2} \mathrm{C}}{\stackrel{\mathrm{C}_{6} \mathrm{H}_{5} \mathrm{CH}-\underset{1}{\mathrm{~K}}}{\mathrm{C}}} \stackrel{\mathrm{CHC}_{6} \mathrm{H}_{5}}{\stackrel{\mathrm{CO}_{2}}{\longrightarrow}}
\end{aligned}
$$

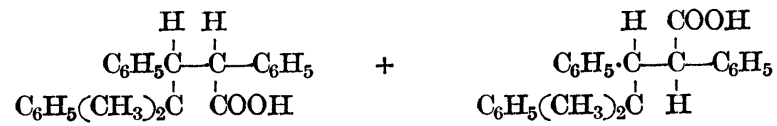

同氏は之に端緒を得て種々の不飽和炭化水素に反應せしめ之等附加成績體及び重合體の 構造 
を明かにして更に進んで Schlenk のアルカリ金屬重合體の構造を明かにせんとした

先づ有機アルカリ 金屬化合體の重合作用能力（Polymerisierungswirkung）を比較すると上 記分類中 I 屬の物は能力のある事確實てあるが取扱ひ困難で詳細に研究されてるない II 屬は $\mathrm{Ar}-\mathrm{CKR}_{2}$ 型は强く, $\mathrm{Ar}_{2}=\mathrm{CKR}, \mathrm{Ar}_{3}=\mathrm{CK}[\mathrm{Ar}: \mathrm{Aryl}, \mathrm{R}: \mathrm{Alkyl}]$ は弱い. 例へば $\left(\mathrm{C}_{6} \mathrm{H}_{5}\right)_{3} \mathrm{CNa}$ は Styrol, Butadien は重合せしめるが Stilben には反應しない. III 屬は最も重合力が弱いも のである.

Phenylisopropylkalium 及び不飽和岑化水素の等量をエーテル中に放置すると短時間て次の如 き炭化水素は附加體を作る。

Aryl 基に隣接したエチレン類，Butadien 等の Dren 類及び Authracen の如き芳否體. 之 等の附加體を例示すれは次の如くである.

A. エチレン類 (Ann. 473,1$)$

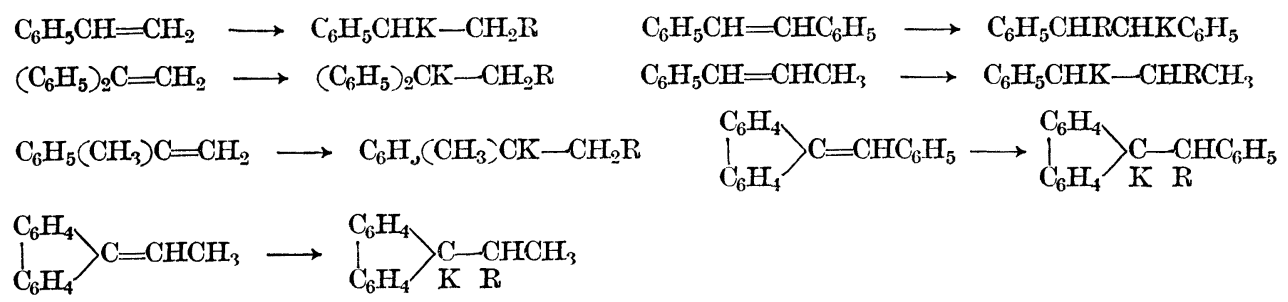

例外として次の如き一群のェチレン類は置換反應を行ふ。
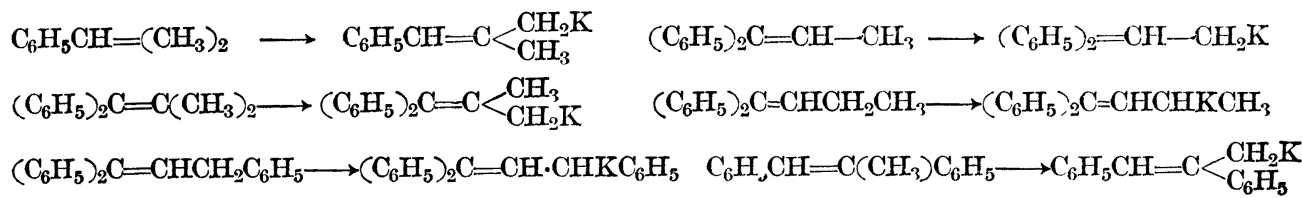

此の置換反應を行ふ物を通覽するとエチレン基に 結合するメチル基とフェニル基の數に 特徴 がある样である。

又附加反應と置換反應の反應速度を比较すると前者が瞬閒的に 反應するのに反し後者は 1-

\section{4 時間を要する.}

上記兩反應は何れもェーテル中に於て反應せしめ炭酸を飽和して斯くして成生したカルボン 酸の吟味に由り成績體の構造を知り得る。

附加成績體は常に赤色に首色し，アルカリか Aryl の隣へ位置する事を豫想せしめるが侗次 の事實で確實である，即ち Diphenylathylen と $\mathrm{Li} \mathrm{C}_{4} \mathrm{H}_{9}$ を反應せしめ之に炭酸を通じて成生 したカルボン酸は別途に合成した Diphenyl-n-amylessigsaure に一致するが故此の反應は次の 如く表す事が出來る. 


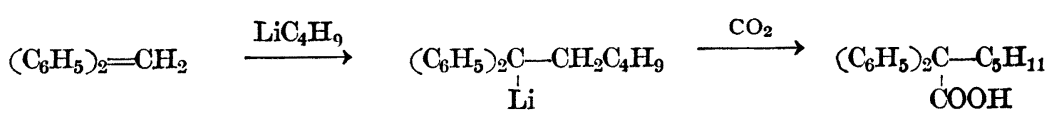

故に上記附加成績體の構造は確實であると考へて良い，晌置換體に付ては大部分の物をカル ボン酸の合成に由り構造決定を行つてるる.

B. Dien 類 (Ann. 511, 13)

等量の Phenylisopropylkalium と Butadien を反應せしめた場合 1,4 附加反應及び 1,2 附加 反應が考へられる。

$$
\stackrel{1}{\mathrm{CH}_{2}} \stackrel{2}{\stackrel{2}{\mathrm{CH}}} \stackrel{3}{-} \mathrm{CH}=\stackrel{4}{\mathrm{CH}}=\mathrm{CH}_{2}
$$

Butadien

$$
\mathrm{R} \mathrm{CH} \mathrm{H}_{2}-\mathrm{CH}=\mathrm{CH}-\mathrm{CH}_{2} \mathrm{~K}
$$

1,4-Addukt
$\mathrm{R} \mathrm{CH}_{2}-\underset{\mathrm{K}}{\mathrm{CH}}-\mathrm{CH}=\mathrm{CH}_{2}$

1,2-Addukt

此の反應成績體に水を加へ復生したオレフィンのオジン分解を行ふと $\beta, \beta$-Dimethyl-hydrozimmtaldehyđ 及び Acetaldehyd を得る事が出來た. 故に 1,4 附加體である事明白である.

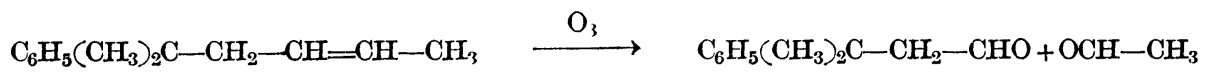

又 Isopren に同樣の反應を行ふと $\mathrm{C}_{6} \mathrm{H}_{5}\left(\mathrm{CH}_{3}\right)_{2} \mathrm{C}-\mathrm{CH}_{2} \mathrm{CHO}$ 及び $\mathrm{C}_{6} \mathrm{H}_{5}\left(\mathrm{CH}_{3}\right)_{2} \mathrm{COCH}_{3}$ がとれ る.之は 1,4 附加反應が二样に行はれたと解すれば良い。

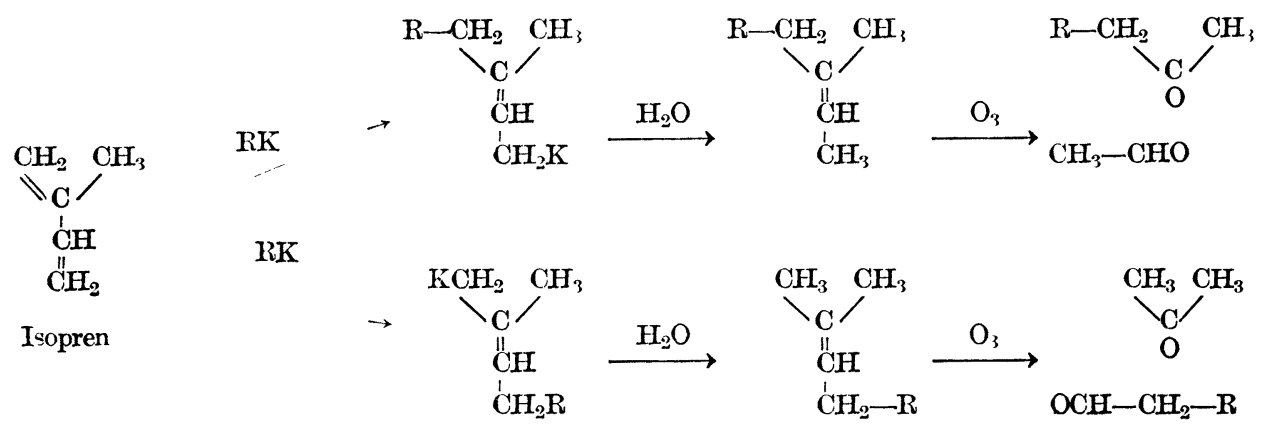

以上の結果から Dien の附加體は逝常の附加反應と同㥞 1,4 附加反應である事明かである.

C. Fulven 類 (Ann 511, 101).

Dimethylfulven, Dimethylbenzofulven, Benzalinden 等に Li $\mathrm{C}_{6} \mathrm{H}_{5}$ を反應せしめると附加成 績體を得る。

Fulven 類の附加反應は 1,2 附加反應なりや 1,4 附加反應なりや未だ明かでない. 假に 1,2 附加反應なりとすれば下記の如く現す事が出來るが 3 の例に於て成生する Fp 115-116 Inden は會て Courtot（C r 160,523）かＦp 161の Inden よりアルカリに由り二重結合 
1.<smiles>[Te][Tl]</smiles><smiles>C[13CH](C)[As](C)C</smiles>

2.<smiles>CC(C)=C(C)c1cccc(C)c1</smiles>

3.<smiles>CCCCC(C)C1C=CC=CC(C)C1</smiles><smiles>CCCCC(C)C(C)c1ccccc1C</smiles>

Fp $161^{\circ}$<smiles>CCC(C)(C)C(C)(CC)CC</smiles><smiles>CCCC(C)(C)C(C)(C)c1ccccc1C</smiles><smiles>CC</smiles><smiles>CCC(C)C(C)(C)c1ccccc1C</smiles>

$\stackrel{\mathrm{KOH}}{\longrightarrow}$

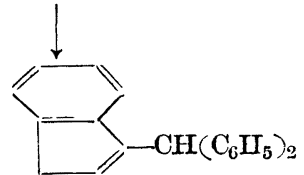

Fp $115-116^{\circ}$

の轉移に由つて得て物質と全く同一物である．從つてリチウム附加體が扣水分解に際してアル カリに由つて二重結合の轉移を行ひ Fp 115-116 の物質に移行したものと考へれは上記の如

\section{く 1,2 附加反應で說明出來る}

\section{Anthracen (Ann 473, 1)}

Anthracen と Phenylisopropylkalium は 9,10 位置の附加成績體を作るか Phenanthren の場 合は 2 モルの重合體を得る。此物は W Schlenk が Phenanthren と金屬カリの反應に於て得 たものと同一物である.
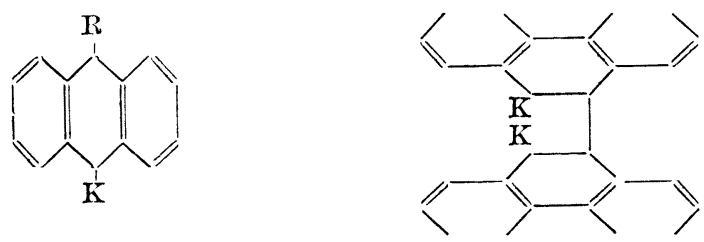

II. 重合反隹 (Ann 473, $57 ; 511,13)$

Phenylisopropylkalium を過剩の Butadien に作用せしめると Butadien が 1 モルの場合は 赤色, 2 モルの場合は橙叀色, 3 モルの場合は摃色を呈する. 郎ち Butadien の量が增加すると 漸次淺色的變化が認められる．郎ちアルカリ金屬か Aryl 基から遠い炭素に移動する事か想像 される. 此の機作を 1,4 附加反應で表はすと次の如くである.

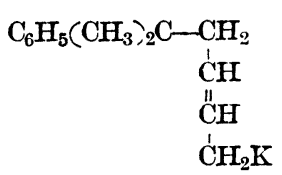

1 モルの附加體

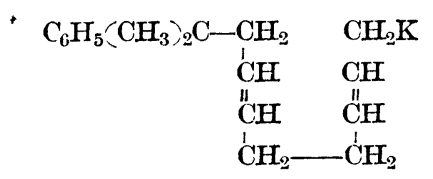

2 モルの附加體

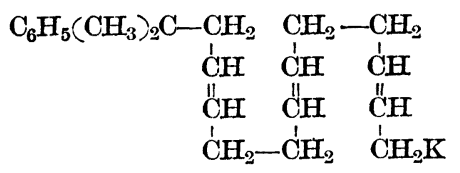

3 モルの附加體 
斯くして得た附加體を炭酸に由りカルボン酸に誘導し其の銀艋の分析に由つて分子量を測定 すると次の如くにをる.

$\begin{array}{lrrrrrrr}\text { Mol. Butadien } & 0 & 2 & 3 & 4 & 5 & 7 & 8 \\ \text { Aequivalent d. Saure } & 164 & 218 & 268 & 302 & 363 & 417 & 493\end{array}$

即ち Butadien の增加に伴ひ附加成績體の分子が大きくなる事は良く了解出來る.

此の重合體の構造を明らかにする穒め $\mathrm{K} \mathrm{Z}$ egler は先づ $\mathrm{Li} \mathrm{CH}_{2} \mathrm{C}_{6} \mathrm{H}_{5}$ と Butadien の重合 反應を行つた，1,4-附加反應が行はれるものとすれは次の如くなる.

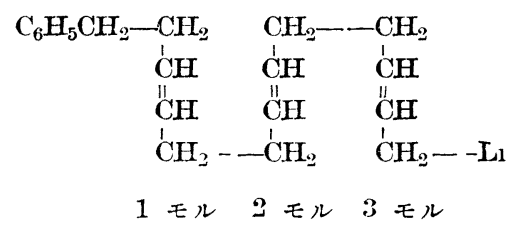

此の附加體を加水分解して炭化水素を遊離し，接觸還元に由つて飽和炭化水素に誘導して分 溜を行つた. 1 モルのブタヂェン附加體からn-Amylbenzol, 2 モルの附加體から n-Nonylbenzol, 3 モルの附加體からは n-Tridecylbenzol を得るべきである，然るに n-Amylbenzol に相當する 溜分からは當該物質を證明し得たのであるが殘餘の溜分は全く純粹になし得ず n-Nonylbenzol, n-Tridecylbenzol 等惊證明し得なかつた。

又同樣にして $\mathrm{C}_{4} \mathrm{H}_{9} \mathrm{Li}$ と Butadien を反應せしめ得を炭化水素を接觸還元すると炭化水素の 混合物を得るのであるが 2 モルの Butadien 附加體である Dodekan の溜分から逐に Dodekan の結晶を得る事が出來なかつた，以上の反應を綜合すると Phenylisopropylkalium, Butadien 等 量宛の場合は正しく 1,4 附加反應が行はれてるるか Butadien が多くなると得た重合體は純然 たる 1,4 體では無いらしく思はれる，K Z Zegler は劣重合體のオジン分解を行つてねるが Formaldehyd を證明し得なかつた，郎ち 1,2 附加體の場合は Formaldehyd を成生すべきであ るから 1,2 附加反應は行はれないと見るべきである.

III. 接觸重合反應 (Ann. 511，45)

以上の重合反應は次の二段に分ける事が出來る.

I. $\mathrm{RA}+\mathrm{Bu}=\mathrm{R}(\mathrm{Bu}) \mathrm{A}$

II. $\mathrm{R}(\mathrm{Bu}) \mathrm{A}+\mathrm{Bu}=\mathrm{R}(\mathrm{Bu})_{2} \mathrm{~A}$ $\mathrm{R}(\mathrm{Bu})_{2} \mathrm{~A}+\mathrm{Bu}=\mathrm{R}(\mathrm{Bu})_{3} \mathrm{~A}$

I の反應速度が II の其れに比して著しく小さい場合 RA は反應の圈外に取殘され殘留し $\mathrm{R}(\mathrm{Bu}) \mathrm{nA}$ なる Hochpolymer のみを得る事が豫想される. 事實 Triphenylmethylnatrium の如 き重合能力の弱い物と過剩の Butadien を反應せしめるとTriphenylmethylnatrium の減量は殆 
ど認められす樹指樣の Hochpolymer のみを得る．此の反應は一見接觸反應の如く見られるの であるが K. Ziegler は巧妙なる方法に由つて I の反應階程に於て 1 モルの附加體を遊離せし める事に成功した.

二級アミン例へば Cyclohexylamin に新して $\left(\mathrm{C}_{6} \mathrm{H}_{5}\right)_{3} \mathrm{CNa}$ は反應しないが $\mathrm{RCH}_{2} \mathrm{Na}$ 型の化 合物は瞬間的に反應してアルカリ金屬は二級アミンと置換する.

$$
\mathrm{RA}+\mathrm{R}_{2} \mathrm{NHI}=\mathrm{RH}+\mathrm{R}_{2} \mathrm{NA}
$$

故に Triphenylmethylnatruum と Butadıen の附加成績體は I の反應階程に於て直ちに二級ア ミンと反應して次ぎの如く進行すべきである.

$$
\begin{aligned}
& \left(\mathrm{C}_{6} \mathrm{H}_{5}\right)_{3} \mathrm{CNa}+\mathrm{CH}_{2}=\mathrm{CH}-\mathrm{CH}=\mathrm{CH}_{2} \longrightarrow\left(\mathrm{C}_{6} \mathrm{H}_{5}\right)_{3} \mathrm{C}-\mathrm{CH}_{2}-\mathrm{CH}=\mathrm{CH}-\mathrm{CH}_{2} \mathrm{Na} \\
& \stackrel{\text { Amin }}{\longrightarrow}\left(\mathrm{C}_{6} \mathrm{H}_{5}\right)_{3} \mathrm{C} \cdot \mathrm{CH}_{2}-\mathrm{CH}=\mathrm{CH}-\mathrm{CH}_{3}+\mathrm{AminNa}
\end{aligned}
$$

事實此の方法に由り Ziegler は Fp $83^{\circ}$ 及び Fp $124^{\circ}$ のチストランス兩型の Triphenylmethylbutylen の遊離に成功した。

此の事實からして一見接觸反應の如く見られる此の重合反應も一般有機アルカリ金屬化合物 に的る重合反應と同樣の反應機作に由り說明し得る譯である。

\section{Dien 類に對するアルカリ金䐂の反應 (Ann, 511, 64)}

Dien 類がアルカリ金屬に由り重合する事は古くから知られ又 Butadiendinatrium に關して は Schlenk の報告があるが其の構造に就ては全く知られてねない

K Ziegler 任第二級 Amı を使用する事に由り Dien 類とアルカリ金屬の第一階程反應に 於ける附加成績體の構造を知る事が出來た. 即ち Methylanilin 存在の下に 2,3-Dimethylbutadien とナトリウムを反應せしめると次の徑路に由り Tetramethylathylen が成生する.

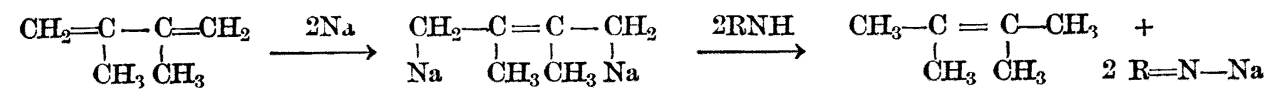

全く同樣にして Styrol から Aethylbenzol, Naphthalin から 1,4-2 H-naphthalin を得てるる.

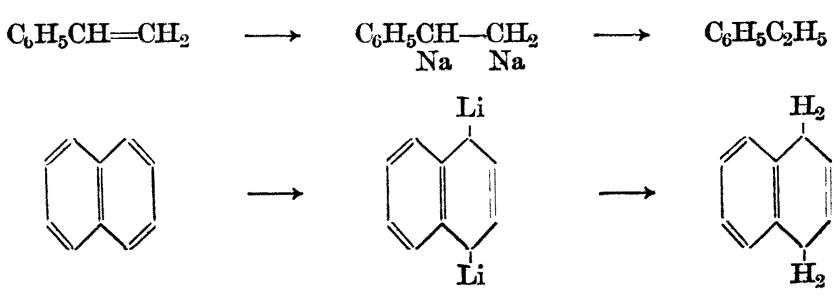

故に Dien の 1,4 位置にアルカリが附加する事が明かである. 份 Hochpolymer の構造に關 しては上記有機アルカリ金屬化合物の重合反應を考慮し, 此の際 1,4 附加反應が純粹に行はれ るものと假定すれば次の如く書ける。 


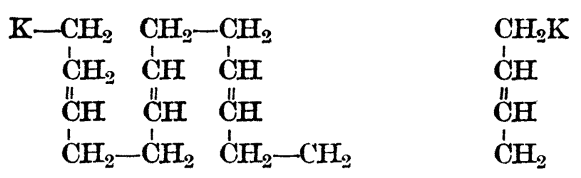

此の問題は有機アルカリ金屬化合物に由る重合體の構造と同樣將來に殘された宿題であつて 近き將來に解決され得る事と信ずる。

異性環壯體に對する反應

$\left(\mathrm{C}_{6} \mathrm{H}_{5}\right)_{2} \mathrm{C}=\mathrm{NC}_{6} \mathrm{H}_{5}$ に對するアルカリ金屬の附加反應は序言に於て速べた如くであるが Pyridin, Chinolin 等の異性環內の $>\mathrm{C}=\mathrm{N}$ - 二重結合に有機アルカリ金屬化合體が如何に反應す るかは興味ある問題である. 又此の反應をグリニャール反應と比挍爼上に乘せる事に由つて何 興味は倍加する.

A. Pyridin. (B 63, 1847)

Bergstrom [J Am Chem Soc 52, 2815 (1930)]は Pyridin をェーテル中でグリニャール 試藥と作用せしめ更に閉管內で $150^{\circ}$ に加熱する事に由り $a$-Aethylpyridin， $a$-Phenylpyridin を $45 \%$ の收量を以て製した。

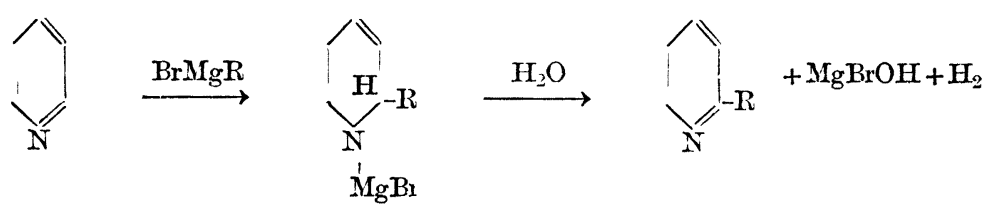

更に叉 Bergmann (J. pr. Chem. 135 (1932), 267) は Benzylmagnesiumchlorid を Dioxan 中で Pyridin に冷時反應せしめて $a$-Benzylpyridin を得てるる.

Pyridin に對する有機アルカリ金屬化合物の反應は K. Ziegler に由り始めて行はれグリニヤ ール試藥と同樣に進行する事が明らかにされた 郎ち $\mathrm{Li}_{4} \mathrm{H}_{9}$ のベンッォール溶夜に Pyridin を加へると發熱反應し加水分解に由つて監基を 分離すると $a-$ Butyl-2 H-Pyridin を與へる 佾 反應成績體をベンツォール溶液の儘閉管內で $100^{\circ}$ K 3 時間加熱すると $\mathrm{LiH}$ を放つて $a-$ Butylpyridin 凡移行する.

B. Pyridinhomolog. (Aun. 485, 174: J. pr. Chem 135, 267 : 本誌 56, 16).

$a$-Picolin $\odot \mathrm{CH}_{3}$ 基は Fluoren, Inden

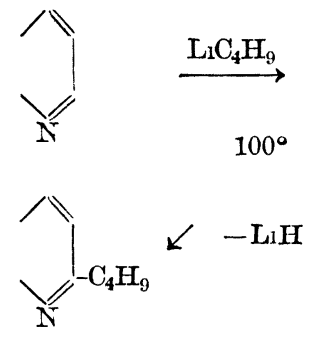

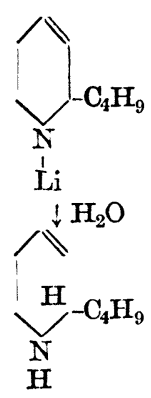

活性メチレン基と 同樣活性を有する事既に 諸種の反應に於て 明らかであるが，之に Li-Alkyl のベンツォール溶液を加へると赤色の成績體を得る. 之に. Benzoylchlorid を作用せしめると 
<smiles>CCc1ccccc1</smiles><smiles>Brc1ccccc1</smiles>

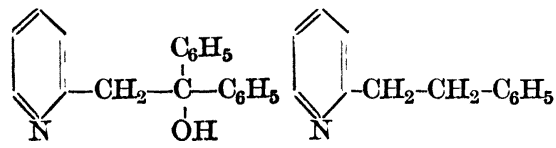

a-Phenacylpyridin を成生するが故に $a$ のメチ ル基に Li の置換した化合物である事明かであ る. 又此の化合體は Halugenalkyl, Benzylchlorid, Benzophenon と圖の如く反應するが故 Pyridin 誘導體の合成原料として重要である.

2,6-Lutidin に於ては之に Li-Alkyl を作用 せしめると $a, a^{\prime}$ のメチル基は同時に $\mathrm{Li}$ と置 換し之に Benzylchlorid を作用せしめると $a, a^{\prime}$ -

Dibenzyllutidin を得る事が出來る。

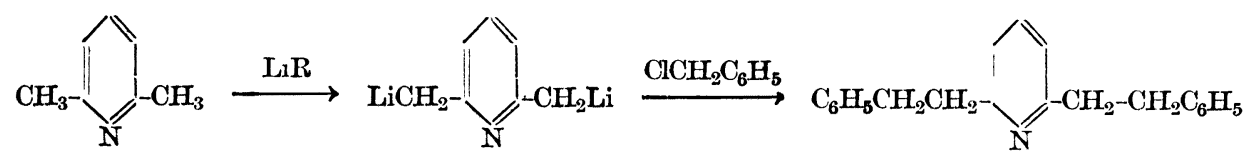

$a$-Butylpyridin 及び $\mathrm{Li} \mathrm{C}_{4} \mathrm{H}_{9}$ は大部分は Pyridin と同栐に進行して $a, a^{\prime}$-Dibutylpyridin に移行するが一部は $a-P i c o l i n$ の場合の如く $a$ のメチル基に $\mathrm{Li}$ が置換する.

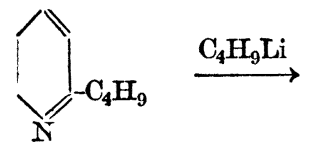

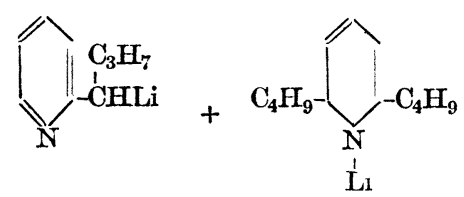<smiles>C/C=C\C(CCC)=NCCCC</smiles>

C Chinolir (Aun. 485, 174, J. pr. Chem. 135, 267)

Bergmann は Chinolin 及び $\mathrm{C}_{6} \mathrm{H}_{5} \mathrm{CH}_{2} \mathrm{Mg} \mathrm{Br}$ を Dioxan 中て反應せしめ 2-Benzyl, 4-Benzyl, 2,4-Dibenzylchinolin の三種を得てるるが, Pyridm の場合に 2-位㗐のみの置換體を得たのに 反し，2,4 兩位置の置換體を成生するのは興味ある事實である.

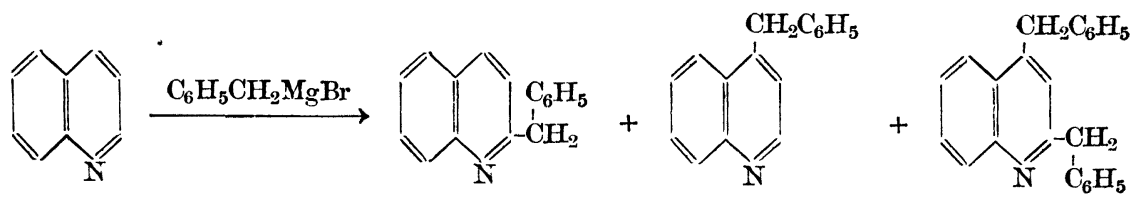

Chinolin と Li-Alkyl は Pyridin の場合とほぼ同樣に反應するが附加成績體から LiH の離 㧤反應は Pyridin の場合の如く順調に進行せす收量 $55 \%$ である. 然るに附加成績體から加水 分解して得られる $2 \mathrm{H}-$ Chinolin 誘導體をニトロベンツォールと加熱すると $80 \%$ の收量を以 て Chinolin 誘導體に移行する.

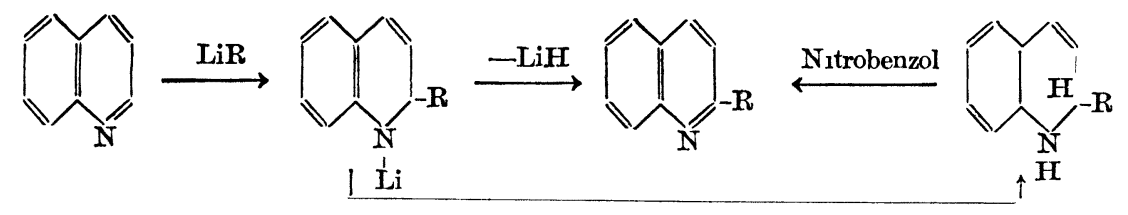


Chinaldin は $a$-Picolin と全く同樣に反應する.

D Isochinolin (J. pr. Chem. 135, 267).

Dioxan 中で $\mathrm{C}_{6} \mathrm{H}_{5} \mathrm{CH}_{2} \mathrm{Mg} \mathrm{Br}$ を作用せしめると 1-Benzyl-2 H-isochinolin を成生するが， Dioxan を使用せぬと 1-Benzyl-isochinolin を與へる。<smiles>c1ccc2cnccc2c1</smiles><smiles>Cc1ccc(Br)cc1</smiles><smiles>c1ccc2ccccc2c1</smiles><smiles>c1ccc(Cc2ccccc2)cc1</smiles>

Li-Alkyl も全然同樣の附加體を生成するが $\mathrm{LiH}$ の離脫反應は Chinolin よりも更に惡く 11\%に過ぎ。. 故に此の場合も $2 \mathrm{H}$-isochinolin を遊離した後ニトロベンツールで酸化すると 順調に Isochinolin 誘導體に移行する.

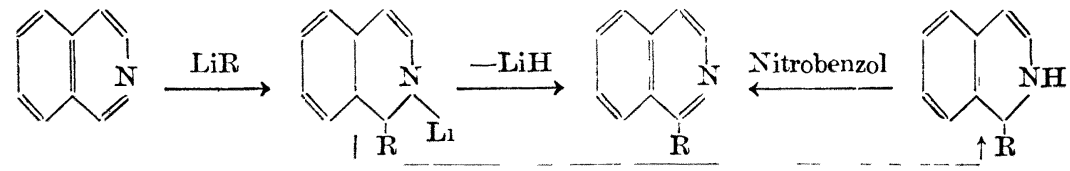

E. Acridin (Ann. 483, 80 ; J. pr. Chem. 135, 267).

Acridin と $\mathrm{C}_{6} \mathrm{H}_{5} \mathrm{CH}_{2} \mathrm{Mg} \mathrm{Br}$ は Dioxan 中で反應して 9,10-Dihydro-9-benzylacridin を成 生する。

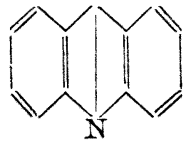

$$
\underset{\text { Dioxan }}{\stackrel{\mathrm{C}_{6} \mathrm{H}_{5} \mathrm{CH}_{2} \mathrm{MgBr}}{\longrightarrow}}
$$<smiles>CCCC1c2ccccc2NC2C=CC=CC21</smiles>

$\mathrm{Li} \mathrm{C}_{4} \mathrm{H}_{9}$ を作用せしめても全然同樣の 附加體を成生するが $\mathrm{LiH}$ を全く離脫しないが故に $2 \mathrm{H}$-Acridin 誘導體入誘導し酸化水銀で酸化すると順調に Acridin 系へ移る.<smiles>C=CC1=C(C=C)N2CC1c1ccccc12</smiles><smiles>c1ccccc1</smiles>

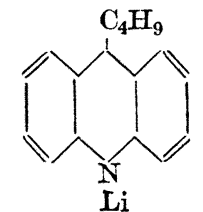

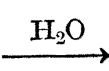

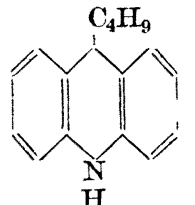

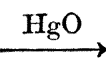

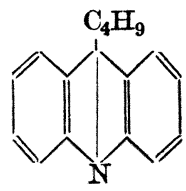

又 9,10-Dihydro-acridin に $\mathrm{LiC}_{2} \mathrm{H}_{5}$ を作肘するとエタンを發生して $\mathrm{Li}$ は空素に置換し之に ヨードメチルを加へると N-Methyl-2H-acridin を成生する.<smiles>c1ccc2c(c1)Cc1ccccc1N2</smiles><smiles>c1ccccc1</smiles><smiles>Cc1ccccc1Cc1ccccc1[AlH]</smiles><smiles>[Mg][Mg]</smiles><smiles>CN(C)c1ccccc1Cc1ccccc1</smiles> 
ニトリルに對する反應 (Ann. 479, 84-112)

ニトリル基は周知の如くグリニャール試藥に由つてケトイミド基に誘導されるが有機アルカ リ金屬化合體例へば $\mathrm{LiC}_{4} \mathrm{H}_{9}$ は之と同樣にニトリル基に作用してケトイミドを成生する，例人 ば Isobutyronitril は $\mathrm{LiC}_{4} \mathrm{H}_{9}$ に由りケトイミドを經て Isobutyl-n-butylketon になる。

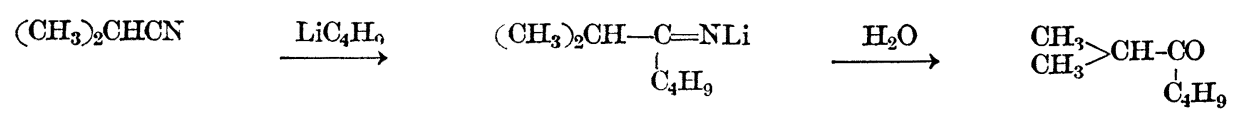

然るに Li-amid 類例へは Li-diathylamid をニトリルに作胢すると全然此の樣な附加反應を 行はない. 即ち Diäthylamin を $\mathrm{LiC}_{6} \mathrm{H}_{5}$ のエーテル溶液中に加へて此處に成生した Lithiumdiäthylamid $\left(\mathrm{C}_{2} \mathrm{H}_{5}\right)_{2} \mathrm{~N}-\mathrm{Li}$ のエーテル溶夜中に Isobutyronitril を加へ更に Allylchlorid を追加 すると反應成續體として Dimethylallylacetonitril が $82 \%$ の收量を以て成生する.

$$
\underset{\mathrm{CH}_{3}}{\mathrm{CH}_{3}}>\mathrm{CHCN}+\mathrm{LlN}<\underset{\mathrm{C}_{2} \mathrm{H}_{5}}{\mathrm{C}_{2} \mathrm{H}_{5}}=\underset{\mathrm{CH}_{3}}{\mathrm{CH}_{3}}>\underset{\mathrm{Li}}{\mathrm{Ci}}+\mathrm{CN}+\mathrm{HN}<{\underset{\mathrm{C}}{2} \mathrm{H}_{5}}_{\mathrm{C}_{2} \mathrm{H}_{5}}^{\stackrel{\mathrm{CH}_{3}}{\mathrm{CH}_{3}}>\underset{\mathrm{Li}}{\mathrm{C} \cdot \mathrm{CN}}+\mathrm{C}_{3} \mathrm{H}_{5} \mathrm{Cl}}=\underset{\mathrm{CH}_{3}}{\mathrm{CH}_{3}}>\underset{\mathrm{C}_{3} \mathrm{H}_{5}}{\mathrm{C}-\mathrm{CN}}+\mathrm{LiCl}
$$

又 Diäthylacetonitrll に於ても全然同栐であつて Diathylallylacetonitril を得る事が出來る. 此の第二級ニトリルを第三級ニトリルに誘導する方法はグリニヤール試藥を以てしても可能で あつて $\mathrm{C}_{2} \mathrm{H}_{5} \mathrm{MgBr}$ と Dicyclohexylamin とに由つて作つた $\left(\mathrm{C}_{6} \mathrm{H}_{11}\right)_{2} \mathrm{~N}-\mathrm{MgBr}$ Isobutyronitril に加へ更に Allylbromid を反應せしめると77\% の收量を以て Dimethylallylacetonitril を得る.

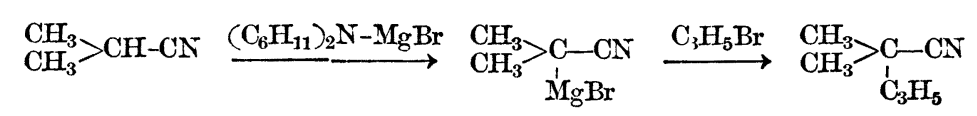

次に第一級アミンの $\mathrm{Li}$ 化合物例へば Lithium-mono-cyclohexylamid $\mathrm{C}_{6} \mathrm{H}_{11} \mathrm{NHLi}$ の反應を 試みると次の樣な興味ある結果を得を。

ての $\mathrm{Li}$ 化合物は Cyclohexylamin を $\mathrm{LiC}_{6} \mathrm{H}_{5}$ のエーテル溶夜に加へる事に由つて成生する.

$$
\Longrightarrow-\mathrm{NH}_{2}+\mathrm{C}_{6} \mathrm{H}_{5} \mathrm{Li}=\longrightarrow-\mathrm{NHLi}+\mathrm{C}_{6} \mathrm{H}_{6}
$$

之に Diäthylacetonitril を加へ竟沸した後 Allylchlorid を加へると 85\% の收量で Amidin が得られる. 郎ち Allylchlorid は反應に全然參與してねない

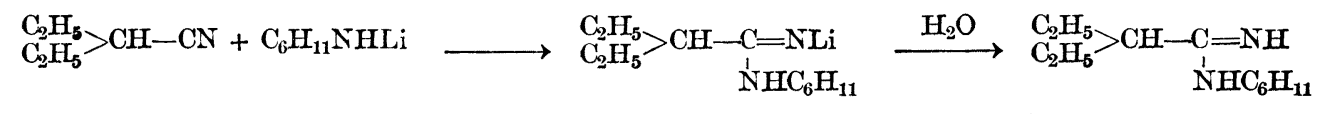

然るに Allylchlorıd と Nitrll の绲夜と Li 化合物のエーテル溶夜を反應せしめると Diathylallylacetonitril が 60\%, Amidin か 17\% の收量で得られる. 即ち主反應は次の如く進行したも のと見て良レ.

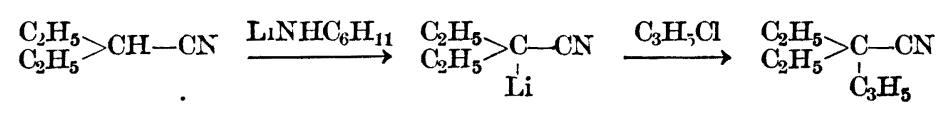


更に興味深々たるものは $\mathrm{NaNH}_{2}$ 及び $\mathrm{LiNH}_{2}$ の反應であつて Diäthylacetonitril $て \mathrm{NaNH}_{2}$ エーテル䋰濁液(製法は略)を作用すると通常の附加反應が行はれて Diäthylacetamidin が $85 \%$ の收量で成生するのであるが

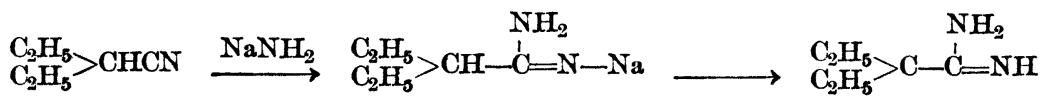

Natriumamid 及 Allylchlorid の混合液とニトリルのベンツォール溶液を $80^{\circ}$ で混攪反應せ しめると 90\% の收量で Diäthylallylacetonitril が成生する. K. Ziegler は此のアルキル化を Natriumamidverfahren と稱し， $\mathrm{Li}-\mathrm{NH}_{2}$ を䏳ひても同样に此の反應が進行する事を確めた.

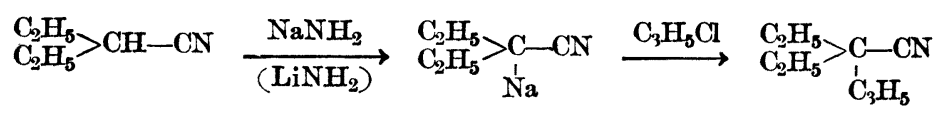

以上述べた反應は第二級ニトリルを第三級ニトリルに誘導する一種のアルキル化反應である が第一級ニトリル例へばアセトニトリルに於ても此の Natriumamidverfahren は可能である. 但しての場合には反應の條件に由り第一級，第二級，第三級ニトリルをそれぞれ成生する.

例へば Acetonitril, Butylbromid, Natriumamid の各等量を使肘するとCapronsäurenitril 60\%, Dibutylacetonitril $9 \%$ の割合で得る事が出來る.

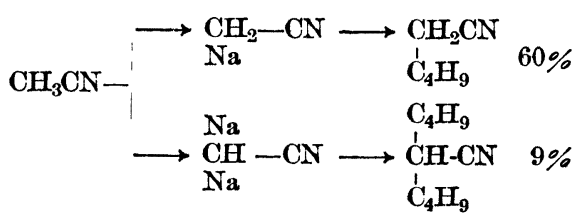

K. Ziegler は脂肪屬ニトリル類に此の Natriumamidverfahren を行ひ多種多样のニトリルを 合成してみる.

閉環反應 (Cyclisation) (Ann. 504, $94 ; 511,1 ; 512,164 ; 513,43 ;$ B. 66, $1867 ; 67,139$ )

K. Ziegler の有機アルカリ金屬化合物の研究中最も絢爛たる篓蹟を擧げたものは此の Cyclisation であつて Ruzicka の Polymethylenketon 合成と共に其の着想の秀でたる蝫に於て何人 も讃灂を惜まぬであらう.

Ruzicka の Polymethylenketon 合成 (Helv. chim. Acta 1926-1933) は高級ヂカルボン酸の Thorium 豋の乾溜に由る方法であつて

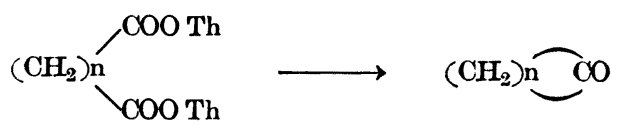

其の收量は圖中 Kurve I に示す如く炭素 7,8. の Keton 即ち Suberon (n=6), Cyclooctanon $-76-$ 
(n=7) に於て 45\%，25\%を示すが炭素 9,10 に於て急に降り，又徐々に上开して炭素 16,17 の Polymethylenketon は最高 $5 \%$ を示し再び降下する.

斯の樣に高級 Polymethylenketon の收量の惡い原因は主として副反應の奚である,例へば分子 內の兩端に $A, B: A^{\prime}, B^{\prime}: A^{\prime \prime}, B^{\prime \prime}$ なる結合原子團がある場合同一分子內で $A \leftarrow B, A^{\prime} \leftarrow B^{\prime}$ なる分子內結合（intramolekulare Verknipfung）を行ふ場合と異なつた分子間に於て結合坫

$$
\left(\begin{array} { l l } 
{ A } & { B }
\end{array} \quad ( \begin{array} { l l } 
{ A ^ { \prime } } & { B ^ { \prime } }
\end{array} ) \quad \left(\begin{array}{ll}
A^{\prime \prime} & B^{\prime \prime}
\end{array}\right.\right.
$$

が聯絡する場合郎ち $\mathrm{A}-\mathrm{B}^{\prime}, \mathrm{B}-\mathrm{A}^{\prime \prime}$ 等の分子外結合 (extramolekulare Verknupfung) が行は れる場合とが考へられる.

Ruzicka の合成法に於て炭素數の少い場合は主として前省が行はれるが炭素數の增加と共に 後者が行はれ易くなりその結果重合體が成生して目的物の收量が减少する. 此の副反應郎ち分 子外結合を避ける唯一の方法は結合反應が同一分子內で進行する椂に非常に稀薄な濃度で行へ ば良い翋である．事實 $\mathrm{HO}\left(\mathrm{CH}_{2}\right) \mathrm{nCOOH}(\mathrm{n}>6)$ なる Oxycarbonsäure の脫水に由つて Lacton を作る反應は非常に稀薄溶液に於てのみ行はれる。

此の樣な見地から K. Ziegler は後述の化學反應を稀薄溶夜に於て行ひ，非常に良好の收量を 以て炭素 7-20 の Polymethylen Keton 類を合成する事に成功した.

ニトリルに對する Li-amid 類の反應は上述の如くである.

$$
\left(\mathrm{CH}_{3}\right)_{2} \mathrm{CH}-\mathrm{CN}+\left(\mathrm{C}_{2} \mathrm{H}_{5}\right)_{2} \mathrm{NLi}=\left(\mathrm{CH}_{3}\right)_{2} \mathrm{C}-\mathrm{CN}+\left(\mathrm{C}_{2} \mathrm{H}_{5}\right)_{2} \mathrm{NH}
$$

此の反應を次の如く進行せしめる事は出來ないか.

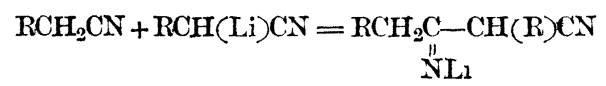

K. Zlegler は $2 \mathrm{~mol} の$ Acetonitril と $1 \mathrm{~mol}$ の Lithiumdiathylamid をェーテル中ー10 で 反應せしめて反應成緽體を加水分解するとAcetessigsäurenitril が 86\% の收量で成生する事を 磼めた。

$$
\begin{aligned}
& \mathrm{CH}_{3} \mathrm{CN}+\mathrm{LlN}\left(\mathrm{C}_{2} \mathrm{H}_{5}\right)_{2}=\mathrm{CH}_{2} \mathrm{~L} \mathrm{CN}+\mathrm{HN}\left(\mathrm{C}_{2} \mathrm{H}_{5}\right)_{2} \\
& \mathrm{CH}_{3} \mathrm{CN}+\mathrm{LiCH}_{2} \mathrm{CN}=\underset{\mathrm{NL}}{\mathrm{CH}_{3} \cdot \mathrm{C}-\mathrm{CH}_{2} \mathrm{CN}} \\
& \underset{2}{\mathrm{CH}_{3} \mathrm{C}-\mathrm{CH}_{2} \mathrm{CN}} \stackrel{\mathrm{H}_{2} \mathrm{O}}{\longrightarrow} \underset{\mathrm{CH}_{3} \mathrm{COCH}_{2} \mathrm{CN}}{\longrightarrow}
\end{aligned}
$$

又全然同㥞にして Butyronitril と Lithuimdiathylamid とに由つて $a$-Butyrylbutyronitrid を 得たのであるが此物は更に $70 \%$ 硫酸で加熱する事に由り Dipropylketon に誘導する事が出來 


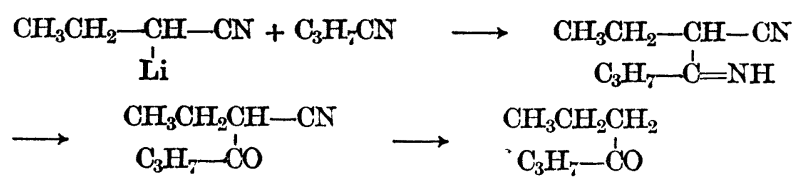

る. ての收量は $68 \%$ である.

此處に於て此の反應を同一分子內で行ひ得るならは Polymethylenketon に到達する道が開抔 される譯であつて，K. Ziegler は先づ Korksäuredinitril を原料とし前迌と同梯の方法に由り 行つてみた。

郎ち Korksäuredınitril を 10 倍量のエーテル溶液にして之を 07 n-Lithiumdiäthylamid エ ーテル溶液に加へた。 此の條件下に Cyancycloheptanon が 13\%の收量で成生, 更に此の物は 48\% HBr で煮坲すると Suberon に移行する.

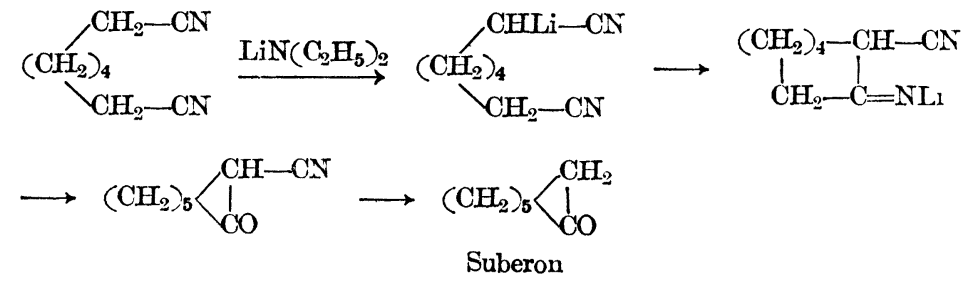

此の收量の惡い原因は副反應である所の extramolek. Verknupf. が行はれをものてあると云 ふ見地から K. Ziegler は此の反應を稀薄溶液に於て行つた。

郎ち三頸コルベン內に $500 \mathrm{cc}$ のエーテルを 入れ㩭排しつつ兩方の大ロから Lithiumähylanilin と Nitril の各々011-n エーテル溶夜を 等速度で 13-14 時間に滴下して反應せしめた. 此の場合の Cyansuberon の收量は $90 \%$ に上つ た. 等速度に兩反應物質を滴下する琵置は圖の 如くであつて $\mathrm{A}, \mathrm{B}$ ，にそれぞれ物質を入れ $\mathrm{C}$ から水銀を滴下すると $\mathrm{u}_{1}, \mathrm{u}_{2}$ 上り兩物質は等速 度に流出し之を反應容器に導く。

一般に 1/100000 n 溶夜に於ては分子內結合反應 は分子外結合反應よりも 10 倍古く進行する.

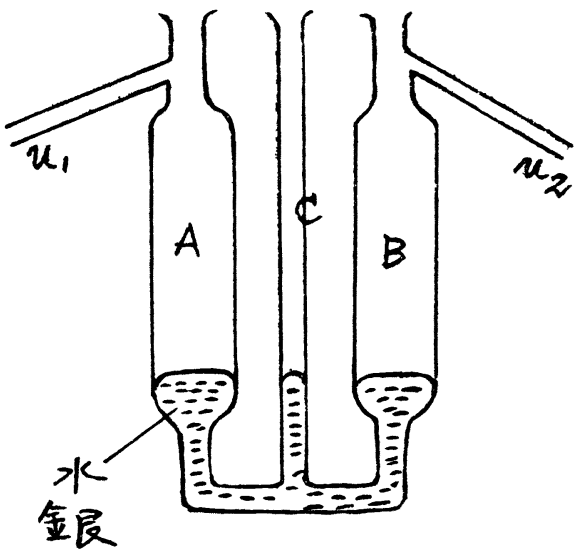
郎ち 1 立のニトリル及び $\mathrm{Li}$ 化合物の $0.1-\mathrm{n}$ 溶 液を 1 立の溶媒中に極めて徐々に等速度に滴下し常に $1 / 100000 \mathrm{n}$ 溶夜で反應が進行する梯に加減 すると目的とする Cyanketon は 90\% の收量で得る事が出來る. 然るに $3 \%$ ニトリルを過剩 に滴下すると收量は $10 \%$ に低下する事を確めた。 
K. Ziegler は Äthylanilin の 如き Aliphatisch-aromatisch の 第二級アミンの $\mathrm{Li}$ 化合物を使 用して高級ヂニトリルを原料と し炭素 7-20 の Polymethylenketon を合成したのであるが其 の收量は圖 Kurve II の如く Ruzicka のそれ (Kurve I)より も比較にならぬ程優秀である.

此の圖表中炭素 9-13の Polymethylenketon は收量が最も惡 的であるが之れは次ぎの樣な 二分子間の反應が行はれる第め である.

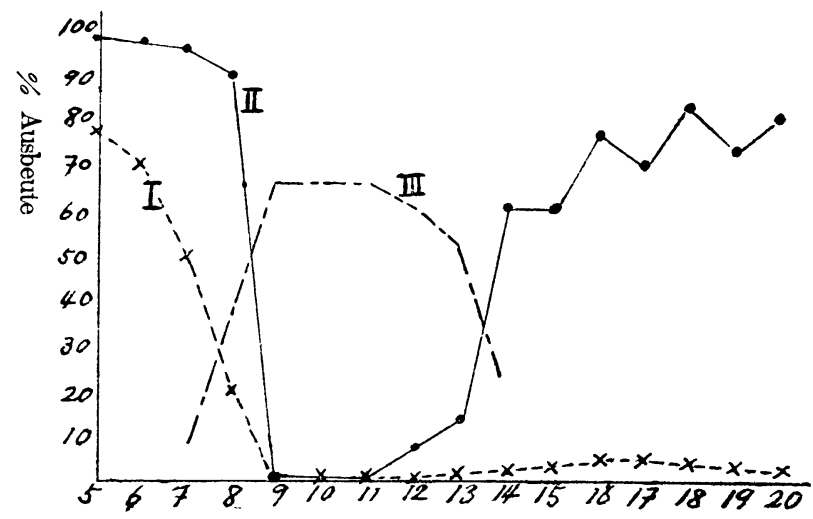

Anzahl d. Ringkohlenstoffatome Cyclisierung nach Ruzika (I) nach Ziegler (II) Dimerisierende Cylisation (III)

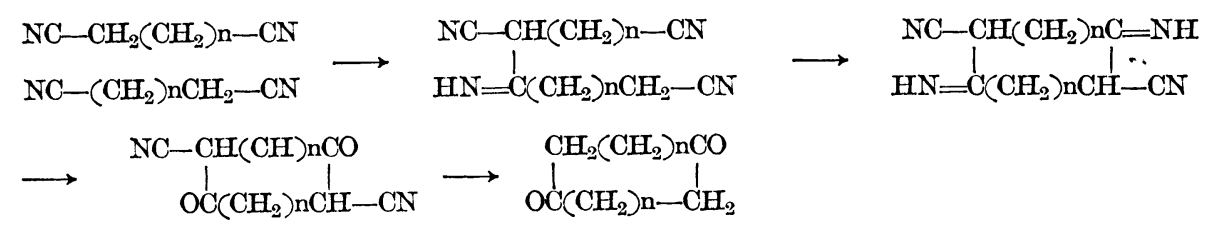

此の Diketon の收量は Kurve III で示す如く炭素 10-11 に於て最高であつて此の場合に は主として Diketon が成生し Monoketon は副反應として出來る事が判る. 又 Kurve II の炎 素 15-20 の間の波狀を呈する原因は明かでないが炭素數の奇數隅數に由つて Ringschlußの難 易があるのは興味ある現像である。

香料として重要である所の Muskon は Rucizka の研究に由り $\beta$-Methylcyclopentadecanon で ある事が明となつたが Ruzicka のカルボン酸監乾溜に由る方法では合成が不可能であつた，K. Ziegler は之の合成を計畫し次ぎの椂な過程を經て rac-Muskon の合成に成功した．此物は天然 のものと全く同样の香を持つものである.

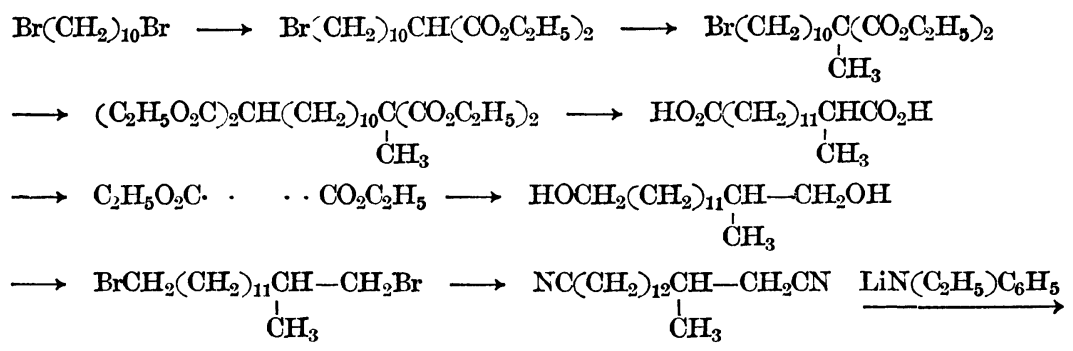




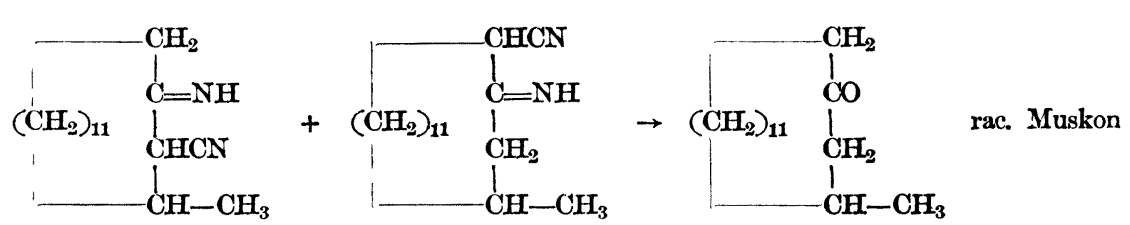

次に K. Ziegler はベンツォール核の meta 及び para にある側鎖の Cyclisation に研究を進 めた。

Ruzicka は Cer 監の乾溜に由つて meta 位置の側鎖の Ringschlußに成功してなるがその收 量は僅かに $2 \%$ に過ぎ。
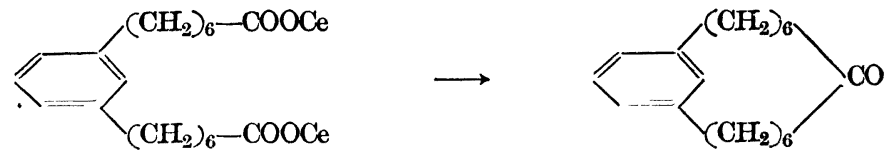

K. Ziegler は Dinatriumresorcin 及び Dinatriumhydrochinon を原料とし次ぎの样な Dinitril を作りその Cyclisation を行つた。
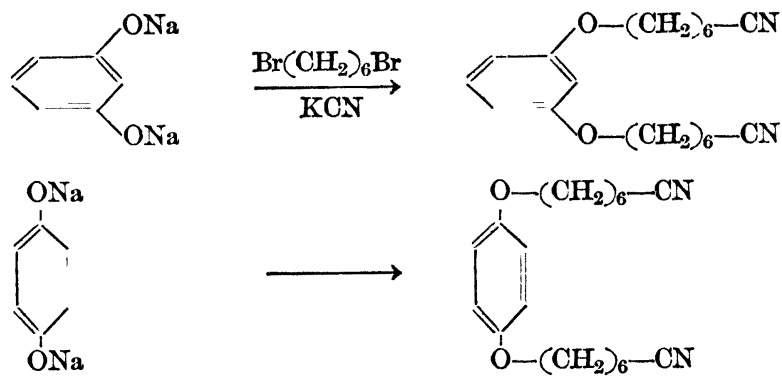

Li-athylanilin を使用して Cyclisation を行ふと 53-52\% の收量で目的物を得る事が出來た.
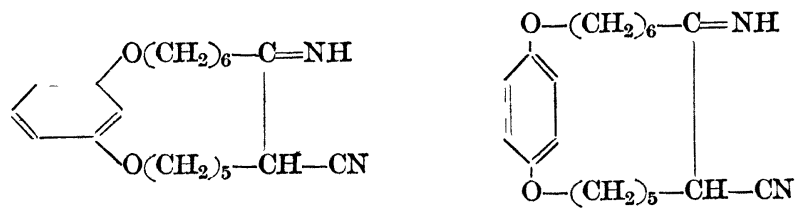

炭素 17 の Polymethylenketon の收量は 70-80\% であるから少し惡い事が解る.

又次の㥞な側鎖の小さんものでは Diketontを成生する.
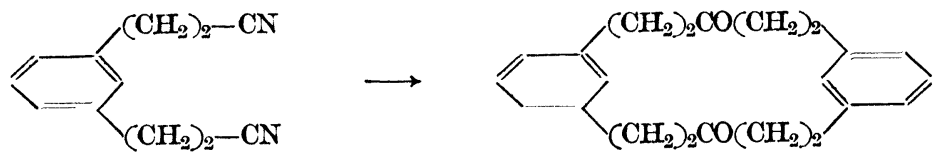

以上䢞べた有機アルカリ金屬化合體の反應は合成化學的見地から眺めても其處に幾多の興味 々眯案を我ふに與へるのであつて此の拙文に由つて讀者が何等かの示崚を得られたならば以て 著者の幸甚とする所である。 